\title{
A Study of the Mechanical Properties of Thermally Treated Recycled Glass Media Used in Vibratory Mass Finishing
}

Mikdam Jamal, Mike Morgan

Liverpool John Moores University, E-mail: m.jamal@2010.ljmu.ac.uk,m.n.morgan@ljmu.ac.uk

This paper reports on the outcomes of a study concerned with the mechanical properties of a new abrasive tool manufactured wholly from thermally treated recycled glass. These properties will aid in understanding the behaviour and performance of the treated glass. Mechanical properties were investigated using the most current and advanced nano-indentation methods. A computer controlled Nano Indentation hardness test (NHT) machine was used to obtain values of hardness and elastic modulus. The nano-indentation process was equipped as a FEM parametric model. The model was then processed by purposely developed numerical objective optimization algorithms in order to determine comprehensive material properties. The aim was to establish the optimal solution with reference to mean square root optimization criterion. The results show large elastic recovery upon unloading similar to a pure silica reference material and a surface roughness unique to this material which is entirely crystalline. The indentation mapping shows significant effect of heat treatment cycles on mechanical properties of recycled glass media.

Keywords: nano-indentation, Finite Element Modelling, Materials properties, Glass, vibratory mass finishing.

\section{Acknowledgements}

The authors wish to extend their thanks to Dr Peter Zioupos (Cranfield University) for his support with the nanoindentation tests.

\section{References}

[1] GILLESPIE K (2007) Mass finishing handbook experimental methods for engineers, Seventh Edition

[2] DOMBLESKY J EVANS R AND CARIAPA V (2004) Material removal model for vibratory finishing International Journalof Production Research 42: 5 1029 - 1041

[3] M. DAO, N. CHOLLACOOP, K.J. VAN VLIET, T.A. VENKATESH, S. SURESH Computational modelling of the forward and reverse problems in instrumented sharp indentation. Acta Mater, 49 (2001), pp. 2899-2918

[4] PHARR M OLIVER AND BROTZEN 1992 On the Generality of the Relationship Between Contact Stiffness. Journal of Materials Research 7 613-617

[5] CHENG Y. T., AND CHENG C. M., 1999b, Scalling relationship in conical indentation of elastic perfectly plastic solids,International Journal of Solid and Structure,Vol.36, pp.1231-1243[6] A.E. Giannakopoulos, S. SureshDetermination of elasto-plasticproperties by instrumented sharp indentationScr Mater, 40 (1999), pp. 1191-1198

[6] R.D. COOK, DS MALKUS, ME. Plesha, 2004. Concept and application of finite element analysis, wiley.

[7] JOHNSON K.L.,1985, Contact mechanics,Cambridge:Cambridge University Press,UK.

[8] SWADDIWUDHIPONG S., THO K.K., LIU K.S.,AND ZENG K.,2005a,Material charecterization based on dual indentors, International Journal of Solid and Structures, Vol.42,pp.69-83.

[9] J. A. KNAPP, D. M. FOLLSTAEDT, S. M. MYERS, J. C. BARBOUR, AND T. A. FRIEDMANN, J. Appl. , 1999. Finite-element modeling of nanoindentation Phys. 85, 1460

[10] S.W. YOUN, C.G. KANG, 2005. FEM study on nanodeformation behaviors of amphous silicon and borosilicate considering tip geometry for pit array fabrication Mat. Sc. and Eng.Vol.390, pp233-239.

[11] KONG X.P.,LI B.,YANG Q.,ENGLISH R.,ROTHWELL G.,AND REN X. J.,2008,Numerical study of the effect of welding parameters on the strength of spot welding joints, Applied Mechanics and Materials, Vol.10,pp.322-326

[12] F TORRES, Y BENINO, T FUJIWARA, T KOMATSU 2002. Evaluation of elastic/mechanical properties of some glasses and nanocrystallized glass by cube resonance and nanoindentation methods Materials Research Bulletin, Vol.62-66, pp: 126-133

[13] LOU J, LIN J, DEAN TA, 2006. Astudy on the determination of mechanical propertyies of a poewer law material by its indentation force-depth curve. Philos Mag. Vol. 86, pp2881-2905. 
[14] LOU J, LIN J, 2007. A study on the determination of plastic properties of metals by instrumented indentation using two sharp indenter. Int. Journal solids structure. Vol. 44, pp5803-5817

[15] M. KOPERNIK, A. MILENIN, R. MAJOR, AND J. M. LACKNER, 2011,Indentification of material model of Tin using numerical simulation of nanoindentation test, Material Scince and Technology, Vol.27, pp.604-616

[16] J.J.KANG, A.A.BECKER,W.SUN, 2012. Determining elastic-plastic properties from indentation data obtained from finite element simulations and experimental results. Int. J. of Mechanical Science.

Paper number: M201227 